\title{
The calcium: an early signal that initiates the formation of the nervous system during embryogenesis
}

\section{Catherine Leclerc *, Isabelle Néant and Marc Moreau}

Centre de Biologie du Développement, Université de Toulouse, CNRS UMR 5547, Toulouse, France and GDRE n 731, "Ca ${ }^{2+}$ toolkit coded proteins as drug targets in animal and plant cells"

\section{Edited by:}

Jose R. Naranjo, Centro Nalcional

De Biotecnologia/Consejo Superior

De Investigaciones Cientificas,

Spain

\section{Reviewed by:}

Jose R. Naranjo, Centro Nalcional

De Biotecnologia/Consejo Superior

De Investigaciones Cientificas,

Spain

Andrew L. Miller, The Hong Kong

University of Science and

Technology, China

*Correspondence:

Catherine Leclerc, Centre de

Biologie du Développement, UMR

CNRS 5547 and GDRE 731,

Université Toulouse III, 118 route de

Narbonne, 31062 Toulouse, France.

e-mail: catherine.leclerc@

univ-tlse3.fr
The calcium $\left(\mathrm{Ca}^{2+}\right)$ signaling pathways have crucial roles in development from fertilization through differentiation to organogenesis. In the nervous system, $\mathrm{Ca}^{2+}$ signals are important regulators for various neuronal functions, including formation and maturation of neuronal circuits and long-term memory. However, $\mathrm{Ca}^{2+}$ signals are also involved in the earliest steps of neurogenesis including neural induction, differentiation of neural progenitors into neurons, and the neuro-glial switch. This review examines when and how $\mathrm{Ca}^{2+}$ signals are generated during each of these steps with examples taken from in vivo studies in vertebrate embryos and from in vitro assays using embryonic and neural stem cells (NSCs). During the early phases of neurogenesis few investigations have been performed to study the downstream targets of $\mathrm{Ca}^{2+}$ which posses EF-hand in their structure. This opens an entire field of research. We also discuss the highly specific nature of the $\mathrm{Ca}^{2+}$ signaling pathway and its interaction with the other signaling pathways involved in early neural development.

Keywords: calcium signaling, EF-hand, neural induction, early neural development, stem cell, neural progenitor, neuro-glial switch

\section{INTRODUCTION}

The formation of the vertebrate nervous system requires the temporally and spatially controlled production of a large number of neuronal and glial cell types. This starts with neural induction, an inductive interaction between the dorsal mesoderm and the dorsal ectoderm which occurs during gastrulation. As a result of this interaction, the dorsal ectoderm adopts a neural fate. This is the pioneer work of Spemann and Mangold in the 1920s (Spemann and Mangold, 1924) in the newt embryo which identified the dorsal mesoderm as the neural organizing center. Equivalent regions were then found in most vertebrates (Waddington, 1933, 1936; Oppenheimer, 1936).

Following neural induction, the dorsal ectoderm or neuroectoderm forms the neural plate which consists of undifferentiated dividing neuroepithelial cells that later during development will exit the cell cycle and will differentiate into neurons and glial cells. Differentiation occurs in defined temporal sequences with neurons generated first and glial cells second. These temporal sequences of early neural development are widely conserved across vertebrate species (Bayer and Altman, 1991). Numerous studies have detailed the diverse signaling pathways that control each sequence (Rowitch, 2004; Stern, 2005; Okano and Temple, 2009; Rogers et al., 2009).

Spontaneous $\mathrm{Ca}^{2+}$ events appear to be common features of developing brain. $\mathrm{Ca}^{2+}$ transients have been observed in dorsal region of embryos as early as gastrulation. In Zebrafish embryo as well as in amphibians, localized $\mathrm{Ca}^{2+}$ transients have been imaged during gastrulation in dorsal region of the embryos, and correlate both temporally and spatially to neural induction (Webb and Miller, 2007). Later on, spontaneous $\mathrm{Ca}^{2+}$ oscillations have been associated with the expansion of the neural progenitors pool.

This review describes how $\mathrm{Ca}^{2+}$ signaling participates in the control of the earliest steps of neural development, including neural induction, followed by the differentiation of neural progenitors into neurons, and the neuro-glial switch. We call these two last steps early neurogenesis (Figure 1). Our goal is to highlight how through the combination of specific $\mathrm{Ca}^{2+}$ toolkit elements (Berridge et al., 2000) calcium can achieve specific functions.

\section{$\mathrm{Ca}^{2+}$ SIGNALING DURING NEURAL INDUCTION}

Neural and epidermal tissues have the same embryonic origin, the ectoderm. In vertebrates, during gastrulation, the cells of the embryonic ectoderm give rise to epidermal progenitors in the ventral side and to neural progenitors in the dorsal side. This binary choice of cell fate is controlled by complex mechanisms that involve positive effectors (Fibroblast Growth Factors, FGFs) and negative effectors (Bone morphogenetic proteins, BMPs; Wingless/Int proteins, Wnts, and Nodal) of neural induction (De Robertis and Kuroda, 2004; Stern, 2005; Gaspard and Vanderhaeghen, 2010). One key regulatory mechanism involved in the conversion of the ectoderm into neuroectoderm is the inhibition of the BMP pathway by noggin, chordin, and follistatin, which are factors secreted by the dorsal mesoderm.

Direct evidence that $\mathrm{Ca}^{2+}$ plays an important role in the choice of fate between neural versus epidermal has emerged through data obtained in the amphibians. In the newt Pleurodeles walt and in 


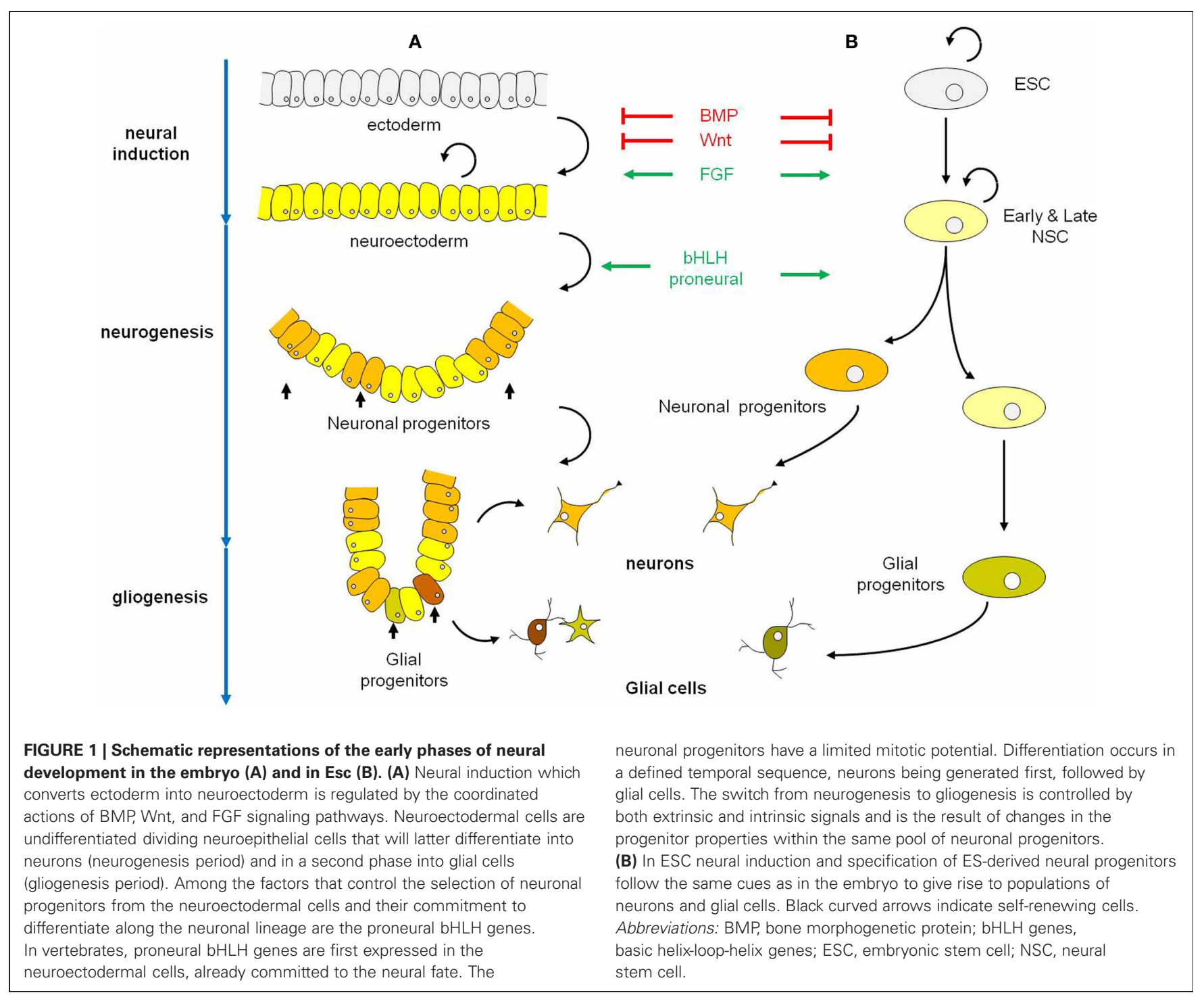

Xenopus laevis embryos, spontaneous elevations of intracellular $\mathrm{Ca}^{2+}\left(\left[\mathrm{Ca}^{2+}\right]_{i}\right)$ are restricted to the dorsal ectoderm cells (the tissue where neural induction takes place) and never occurs in ventral ectoderm cells, which are at the origin of the epidermis (Leclerc et al., 1997, 2000). As gastrulation proceeds, $\mathrm{Ca}^{2+}$ transients increase both in number and intensity, to reach a peak activity by mid-gastrulation, a stage where neural determination is thought to have occurred (Leclerc et al., 2000). The onset of these spontaneous $\mathrm{Ca}^{2+}$ events occurs at the blastula stage, long before the start of gastrulation (i.e., before mesoderm invagination). These observations are in agreement with other results obtained in Xenopus (Sharpe et al., 1987) and in Chick (Streit et al., 2000) suggesting that neural induction starts before gastrulation. At the late blastula stage, the dorsal ectoderm is already biased toward dorsal fate and is more responsive to neural-inducing signals than the ventral ectoderm (Sharpe et al., 1987). Furthermore, direct visualization of the $\mathrm{Ca}^{2+}$ dynamics in Xenopus laevis reveals that the $\mathrm{Ca}^{2+}$ transients are localized in the most anterior part of the dorsal ectoderm. The accumulation of these $\mathrm{Ca}^{2+}$ transients versus time correlates with the prospective neuroectoderm and the $\mathrm{Ca}^{2+}$ transients are probably the first directly visualized events linked to neural induction. Later, during gastrulation, $\mathrm{Ca}^{2+}$ transients are always restricted to the dorsal ectoderm (the prospective forebrain-midbrain) and never occur in the non involuting marginal zone (NIMZ; i.e., the prospective hindbrain-spinal cord).

The ability of the ectoderm cells to be induced and to differentiate toward neural tissue, called neural competence, is acquired shortly before gastrulation and lost during late gastrula stages. In Xenopus, as in Pleurodeles embryos, neural competence is associated with the expression of functional dihydropyridine sensitive $\mathrm{Ca}^{2+}$ channels (DHP-Ca ${ }^{2+}$ channels) in the plasma membrane (Drean et al., 1995; Leclerc et al., 1995). Functional DHP-Ca ${ }^{2+}$ channels first appear in the ectoderm cells at blastula stage. The highest density of DHP-Ca ${ }^{2+}$ channels is reached at mid-gastrula, when competence of the ectoderm is optimal. The decrease of 
the DHP-Ca ${ }^{2+}$ channel density occurs simultaneously with the normal loss of competence, at the end of gastrulation. This temporal pattern of DHP-Ca ${ }^{2+}$ channels expression correlates with the dynamic pattern of $\mathrm{Ca}^{2+}$ transients. DHP-Ca ${ }^{2+}$ channels belong to the large family of voltage-operated $\mathrm{Ca}^{2+}$ channels (VOCCs) composed of a pore forming $\mathrm{Ca}_{\mathrm{v}}$ subunit, associated with regulatory subunits. The $\mathrm{Ca}_{\mathrm{v}}$ subunit is encoded by four genes; $\mathrm{Ca}_{\mathrm{v}} 1.1, \mathrm{Ca}_{\mathrm{v}} 1.2, \mathrm{Ca}_{\mathrm{v}} 1.3, \mathrm{Ca}_{\mathrm{v}} 1.4$ (Catterall et al., 2005). In Xenopus laevis gastrula embryo, the expression of $\mathrm{Ca}_{\mathrm{v}} 1.2$ transcripts is restricted to the dorsal mesoderm and to the inner layer of the ectoderm (Leclerc et al., unpublished data); i.e., the first ectoderm layer to be induced toward neural fate during gastrulation (Chalmers et al., 2002).

The inhibition of DHP-Ca ${ }^{2+}$ channels function by specific antagonists during gastrulation completely abolishes the patterns of $\mathrm{Ca}^{2+}$ transients and decreases the intracellular $\mathrm{Ca}^{2+}$ resting level, suggesting that the patterns of $\mathrm{Ca}^{2+}$ transients are generated via the activation of DHP-Ca ${ }^{2+}$ channels (Leclerc et al., 1997, 2000). The abolition of these $\mathrm{Ca}^{2+}$ transients induces both the downregulation of at least two early neural genes (Zic3 and geminin) and the presence of severe abnormalities in the anterior nervous system. The most apparent defects are a deformation of the head, a reduction in the size or the total disappearance of the eyes, and lack of melanophores (Leclerc et al., 2000, 2001). Acquisition of the neural fate in amphibians therefore requires the expression of functional DHP-Ca ${ }^{2+}$ channels in the ectoderm. Since these channels are VOCCs, this raises the question about the mechanism by which the DHP-Ca ${ }^{2+}$ channels are specifically activated in the dorsal ectoderm during the process of neural induction. Other questions concern the identification of the $\mathrm{Ca}^{2+}$-target genes and the persistence of the role of $\mathrm{Ca}^{2+}$ during neural induction in vertebrates. Some clues will be given in the following paragraphs.

\section{Ex vivo MODELS OF NEURAL INDUCTION}

Two ex vivo models have been particularly useful to decipher the molecular mechanisms involved during neural induction. We will discuss data obtained from mouse embryonic stem cells (ESCs) and from naïve ectoderm (animal caps) isolated from Xenopus laevis blastula. Although the spatial and temporal influences of early vertebrate embryogenesis are missing from these ex vivo assays, the same signals affecting neural induction in developing embryos also regulate neurogenesis in these models (Figure 1). Indeed, FGFs and antagonists of BMP, Nodal and Wnt signaling pathways (for reviews see Cai and Grabel, 2007; Gaulden and Reiter, 2008) have been shown to promote commitment of ESC to Neural stem cells (NSCs). This is also true for Xenopus ectoderm cells. Particularly, any manipulation that reduces BMP signaling neuralizes the animal cap cells. The Noggin protein, a BMP antagonist rapidly induces the expression of neural specific markers in animal cap cells at the expense of epidermal markers (Lamb et al., 1993; Hemmati-Brivanlou and Melton, 1997; Stern, 2005).

\section{THE EMBRYONIC STEM CELLS}

Neural induction studies in mammals have mainly involved the use of ESC due to difficulties in accessing and manipulating early embryos. ESCs are self-renewing and pluripotent cells that give rise to derivatives of all three germ layers (endoderm, ectoderm, and mesoderm). The derivation of specific neuronal and glial cell types from ESC results from different protocols but invariably proceeds through similar steps: (1) induction and production of NSCs, (2) stabilization of cell fate and appearance of radial-glial-like progenitor cells and (3) differentiation of progenitors into a variety of specific neuronal and glial cells derivatives, including dopaminergic, glutamatergic, or GABAergic neurons and oligodendrocytes, respectively (Figure 1).

Evidences indicate that the control of $\mathrm{Ca}^{2+}$ homeostasis is an important regulator of neural fate in mammals. A proteomic analysis to determine the global protein expression changes between mouse ESC and differentiated dopaminergic neurons identified about 20 proteins differentially regulated during neural differentiation (Wang and Gao, 2005). Among these proteins, Wang and Gao identified three $\mathrm{Ca}^{2+}$-related proteins: calreticulin and pyruvate dehydrogenase E1/E2 subunits which are up-regulated, and the Translationally Controlled Tumor Protein (TCTP) which is down-regulated in neurons. TCTP is a $\mathrm{Ca}^{2+}$. and microtubule-binding protein involved in the control of cell proliferation and cell cycle. It is up-regulated upon entry into cell cycle, bound to microtubules during mitosis and detached from the spindle after metaphase (Bommer and Thiele, 2004). TCTP has been shown to regulate $\mathrm{Ca}^{2+}$ uptake and $\mathrm{Ca}^{2+}$ homeostasis in trophoblast cells (Arcuri et al., 2005) and to negatively regulate the $\mathrm{Na}$, K-ATPase activity in HeLa cells (Yoon et al., 2006). Calreticulin is an endoplasmic reticulum luminal $\mathrm{Ca}^{2+}$ buffering protein involved in the regulation of intracellular $\mathrm{Ca}^{2+}$ homeostasis (Michalak et al., 2009) and the E1/E2 subunits of the mitochondrial pyruvate dehydrogenase are activated by $\mathrm{Ca}^{2+}$ (Denton, 2009). Additional studies have started to decipher the role of $\mathrm{Ca}^{2+}$ signaling in neuronal fate induction. Electrical stimulation of embryoid bodies (EBs) induces the differentiation of cells expressing TuJ1, a marker for early committed neuronal cells. The mechanism of this electrical induction requires an influx of $\mathrm{Ca}^{2+}$ that does not involve VOCCs (Yamada et al., 2007).

More recently, a screen to identify genes involved in neural induction in mammals identified Neuronatin (Nnat) (Lin et al., 2010). Nnat is a membrane protein from the endoplasmic reticulum that belongs to the proteolipid family, strongly expressed in specific developing brain structures (Wijnholds et al., 1995). During ex vivo neural differentiation, Nnat is expressed in all steps from ESC to neurons, and reaches a maximum of expression in early neuroectodermal cells. Nnat has been shown to physically interact with the sarco/endoplasmic reticulum $\mathrm{Ca}^{2+}$. ATPase isoform 2 (SERCA2) and to regulate the intracellular $\mathrm{Ca}^{2+}$ level by antagonizing SERCA2 activity. The modulation of $\mathrm{Ca}^{2+}$ homeostasis controls neural induction (i.e., the ability of ESC to produce NSC). While the overexpression of Nnat is associated with an increase in $\left[\mathrm{Ca}^{2+}\right]_{i}$ and the generation of neuroectodermal cells and neurons, knocking down of Nnat reduces the level of intracellular $\mathrm{Ca}^{2+}$ and inhibits neural induction in ESCs (Lin et al., 2010). This latter effect can be rescued with thapsigargin, an inhibitor of the SERCA pump. Furthermore, high $\left[\mathrm{Ca}^{2+}\right]_{i}$ conditions inhibit BMP signaling and interact with the FGF/Erk signaling pathway by increasing the phosphorylation of Erk. 


\section{THE ANIMAL CAP ASSAY IN XENOPUS LAEVIS}

In Xenopus laevis embryo, the ectoderm cells isolated at blastula stage retain their pluripotentiality and upon exposure to specific inducers can differentiate into neural, mesodermal, or endodermal tissues. In this sense, although not self-renewing, the isolated ectoderm cells (or animal cap cells) display behavior similar to mammalian ESCs (Okabayashi and Asashima, 2003).

Barth and Barth (1964) were the first to suggest that in Rana pipiens embryos, $\mathrm{Ca}^{2+}$ is required to induce neuralisation of the ectoderm cells. Following on this early report, it was shown that dissociation of Xenopus laevis and Pleurodeles walt animal caps in $\mathrm{Ca}^{2+}$ - and $\mathrm{Mg}^{2+}$-free medium directed cells towards a neural fate (Grunz and Tacke, 1989; Saint-Jeannet et al., 1990) and was associated with an increase in $\left[\mathrm{Ca}^{2+}\right]_{i}$ (Leclerc et al., 2001). This increase is due to a release of $\mathrm{Ca}^{2+}$ from internal stores, resulting from the reverse gradient of concentration of $\mathrm{Ca}^{2+}$ between intra and extracellular compartments. Dissociation of animal caps preloaded with the $\mathrm{Ca}^{2+}$ chelator BAPTA both abolishes the $\mathrm{Ca}^{2+}$ increase and neural induction (Leclerc et al., 2001). It has been shown that Noggin is one of the endogenous neural inducer by interacting BMP proteins (Zimmerman et al., 1996). Noggin is also able to trigger an increase in $\left[\mathrm{Ca}^{2+}\right]_{i}$ via an influx through DHP-Ca ${ }^{2+}$ channels (Leclerc et al., 1997, 1999, 2000). The direct activation of DHP-Ca ${ }^{2+}$ channels by specific agonists such as $\mathrm{S}(-)$ Bay $\mathrm{K}$ 8644, generates a transient increase in $\left[\mathrm{Ca}^{2+}\right]_{i}$. This increase is sufficient, even in an active BMP context, to trigger not only the expression of neural markers but also the formation of neurons and glial cells (Moreau et al., 1994). In addition, methylxanthines, such as caffeine or theophyline, which are known to stimulate the release of $\mathrm{Ca}^{2+}$ from internal stores, are also potent neural inducers (Moreau et al., 1994; Batut et al., 2005). These data strongly suggest that $\mathrm{Ca}^{2+}$ is a necessary and sufficient signal to initiate neural induction and to promote neural differentiation.

Recent studies suggest that the mechanism by which DHP$\mathrm{Ca}^{2+}$ channels are activated in the ectoderm during neural induction might be via membrane depolarization induced by BMP antagonist and/or FGF signaling (Lee et al., 2009). Both FGF-4 and Noggin depolarize the membrane of ectoderm cells. Furthermore, FGF- 4 induces an increase in $\left[\mathrm{Ca}^{2+}\right]_{i}$ which can be blocked by SU5402, an FGF receptor inhibitor, and by DHP-Ca ${ }^{2+}$ channel antagonists. SU5402 also blocks the induction of neural genes induced by Noggin. The proposed mechanism involves that (1) FGFR activation, most likely via FGFR1 and/or FGFR4, triggers an influx of $\mathrm{Ca}^{2+}$ through non specific cationic channels (namely TRP channels). (2) This initial $\mathrm{Ca}^{2+}$ increase is then able to depolarize the cell membrane (Puro and Mano, 1991; Distasi et al., 1995, 1998; Fiorio Pla et al., 2005), which in turn activates DHP-Ca ${ }^{2+}$ channels. (3) This subsequent influx of $\mathrm{Ca}^{2+}$ amplifies the initial $\mathrm{Ca}^{2+}$ increase and leads to the expression of neural genes (Lee et al., 2009). However, the question regarding how the inhibition of BMP4 signaling by noggin might induce an influx of $\mathrm{Ca}^{2+}$ influx remains to be clarified.

\section{$\mathrm{Ca}^{2+}$ SIGNALING DURING NEURAL INDUCTION IN VERTEBRATES: AN EMERGING MODEL}

Altogether the results obtained from Xenopus and mouse models reveal that the mechanisms that govern neural induction involve the cross-talk between several signaling pathways and specially require the inhibition of BMP pathway, the activation of the FGF/Erk pathway and the control of $\mathrm{Ca}^{2+}$ homeostasis. The general model of neural induction, presented in Figure 2, highlights the similarities and the differences between mammals and amphibians.

The phosphorylation of Erk is a common event that mediates neural fate in vertebrates. In mouse ESC $\mathrm{Ca}^{2+}$ signaling increases the phosphorylation of Erk and triggers neural induction (Lin et al., 2010). In the amphibian the same mechanism is likely to control Erk phosphorylation. It has been shown that dissociation of ectoderm cells triggers a large increase in $\left[\mathrm{Ca}^{2+}\right]_{i}$ (Leclerc et al., 2001) and causes the phosphorylation of Erk (Kuroda et al., 2005). An increase in intracellular $\mathrm{Ca}^{2+}$ concentration appears to be the core signal that controls neural fate determination in vertebrates. This increase in $\left[\mathrm{Ca}^{2+}\right]_{i}$ may result from an influx of $\mathrm{Ca}^{2+}$ through plasma membrane $\mathrm{Ca}^{2+}$ channels and/or release from endoplasmic reticulum $\mathrm{Ca}^{2+}$ stores. However, the route for $\mathrm{Ca}^{2+}$ increase seems different between the amphibian and the mammal models. On the one hand, in Xenopus naïve ectoderm cells an influx of $\mathrm{Ca}^{2+}$ through DHP-Ca ${ }^{2+}$ channels is likely to be the main component of the changes in $\left[\mathrm{Ca}^{2+}\right]_{i}$ observed both in vivo and ex vivo during neural induction (Moreau et al., 2008). Members of the TRP (Transient Receptor Potential) channels family, particularly TRPC1, are probably also involved (Lee et al., 2009). On the other hand, in mouse ESC, investigations to identify the $\mathrm{Ca}^{2+}$ channels and transporters that are expressed in plasma membrane and internal stores reveal the absence of VOCCs. The only plasma membrane $\mathrm{Ca}^{2+}$ channels expressed are TRPC1 and TRPC2 (Yanagida et al., 2004; Wang et al., 2005). $\mathrm{Ca}^{2+}$ release from the endoplasmic reticulum (ER) are mediated by the inositol triphosphate receptors ( $\left.\mathrm{IP}_{3} \mathrm{Rs}\right)$ but not by the ryanodine receptors (RyRs). Both plasma membrane $\mathrm{Ca}^{2+}$-ATPase (PMCA-1) and $\mathrm{Na}^{+} / \mathrm{Ca}^{2+}$ exchanger (NCX-1, -2, -3) contribute to the extrusion of $\mathrm{Ca}^{2+}$ from the cytoplasm (Yanagida et al., 2004). Therefore, in mouse ESC, the main source of $\mathrm{Ca}^{2+}$ comes from internal stores. This is further supported by the identification and the characterization of Nnat function during neural induction in ESC (Lin et al., 2010). However, in amphibians, caffeine has been shown to trigger the expression of specific neural genes in naive ectoderm (Moreau et al., 1994; Batut et al., 2005). This suggests that internal stores may participate in $\mathrm{Ca}^{2+}$ signaling during neural induction in the amphibians. Finally, results obtained from both models suggest a cross-talk between $\mathrm{Ca}^{2+}$ signaling and the BMP pathway. The release of $\mathrm{Ca}^{2+}$ from internal stores via caffeine (Batut et al., 2005) or through inhibition of SERCA2 (Lin et al., 2010) suppresses the expression of BMP4. Whether this cross-talk is direct or involves Erk signaling is still an open question.

\section{$\mathrm{Ca}^{2+}$ SIGNALING DURING EARLY NEUROGENESIS}

The next step in neural development involves the differentiation of neural progenitors into neurons (Figure 3). This step occurs during the radial differentiation of the neural tube. At the time of its closure, the neural progenitors are localized in a single layer of proliferative cells, the ventricular zone (VZ) (Figure 3A). Then during development, two other zones are successively formed. 
Neural induction in Xenopus ectoderm

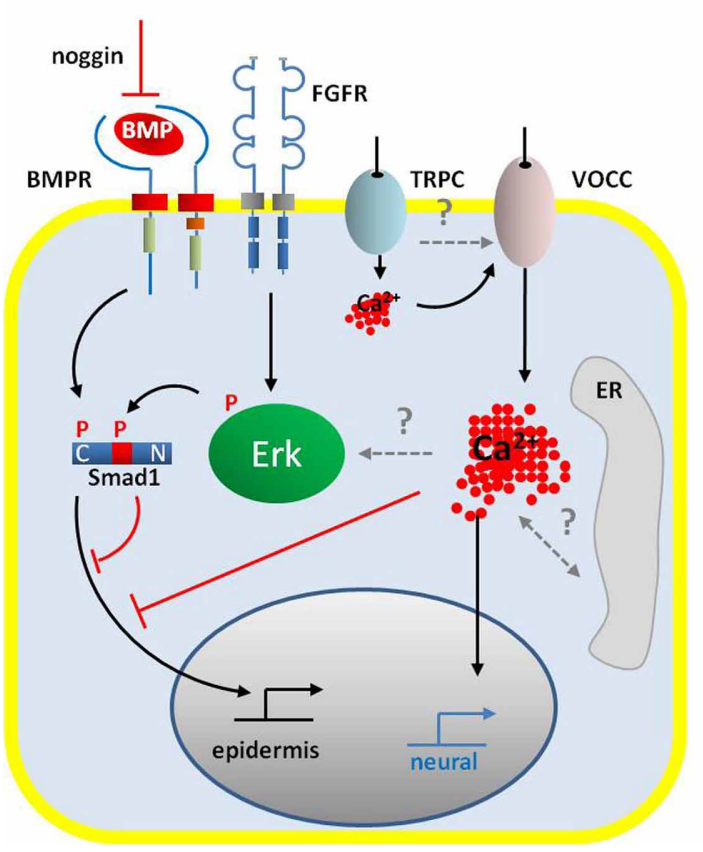

FIGURE 2 | Schematic representation of the signaling pathways occurring during neural induction in the amphibian ectoderm cells (left panel) and in the ESCs (right panel). In both systems, neural commitment of naive cells requires the activation of FGF/ERK signaling and the inhibition of BMP signaling by noggin and via the Erk-dependent phosphorylation of Smad1 at linker domain. An increase in intracellular $\mathrm{Ca}^{2+}$ concentration is also a common signal that drives embryonic cells toward the neural fate. However, the control of $\mathrm{Ca}^{2+}$ homeostasis differs between amphibian ectodermal cells and ESCs. While in amphibian, the main source of $\mathrm{Ca}^{2+}$ increase appears to rely on an influx through VOCCs (likely DHP-Ca ${ }^{2+}$ channels), ESCs do not express VOCC. In ESCs, the regulation of intracellular $\mathrm{Ca}^{2+}$ level depends on the activity of the SERCA2 pump, negatively regulated by neuronatin. Both cell types expressed TRP channels, probably
Neural induction in Embryonic Stem Cells

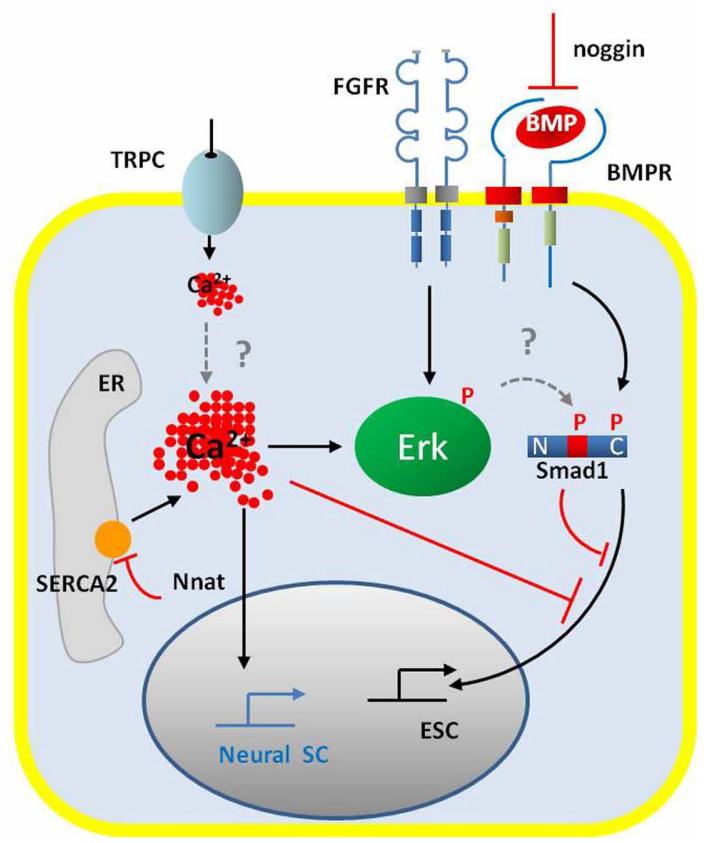

TRPC, which could contribute to the $\mathrm{Ca}^{2+}$ signals. Gating of the VOCC in ectodermal cells could be due to membrane depolarization induced by the activation of TRPC. In ESCs, a direct link between intracellular $\mathrm{Ca}^{2+}$ increase and Erk phosphorylation has been established; in ectodermal cells the question of the amplification of the initial $\mathrm{Ca}^{2+}$ influx by the release of $\mathrm{Ca}^{2+}$ from the ER remains open. However, in both models $\mathrm{Ca}^{2+}$ signals participate in the inhibition of the BMP signaling pathway, either directly or indirectly via Erk-dependent phosphorylation of Smad1. Abbreviations: BMP, bone morphogenetic protein; BMPR, BMP receptor; ER, endoplasmic reticulum; ESC, embryonic stem cell; FGFR, fibroblast growth factor receptor; Nnat, neuronatin; Neural SC, neural stem cell; SERCA2, sarco/endoplasmic reticulum $\mathrm{Ca}^{2+}$-ATPase, isoform2; TRPC, class $\mathrm{C}$ transient potential receptor; VOCC, voltage-operated $\mathrm{Ca}^{2+}$ channels.
The marginal zone (MZ) located between the VZ and the outer surface of the neural tube, followed by the intermediate zone (IZ), between the VZ and the MZ. The VZ contains neuronal progenitors with a more restricted fate than neuroepithelial cells called the radial glial cells (Gotz and Huttner, 2005) and the IZ contains the first postmitotic neurons (Figure 3B). At later stages, different parts of the neural tube display specific organizations. In the spinal cord, the neural progenitors will differentiate into postmitotic neurons, distributed laterally into the IZ. In the cerebral cortex, in birds and mammals, a second proliferative zone, the subventricular zone (SVZ), appears adjacent to the VZ (Figure 3C); the postmitotic neurons arise from both the ventricular and the SVZ zones (Nowakowski and Hayes, 2005). Neural progenitors are produced by asymmetric division of neuroepithelial cells. Self-renewing divisions of the progenitors, such as radial glial cells, can be either symmetric, generating two progenitors or asymmetric, producing a neural progenitor and a neuron (Fish et al., 2008). In the VZ, neuroepithelial cells and neuronal precursor cells undergo interkinetic nuclear migration in which cells in
$S$ phase of the cell cycle have their nuclei in the upper third of the VZ. When cells pass from $S$ to $G_{2}$, the nuclei migrate toward the neural tube lumen where mitosis occurs (Figure 3 and review in Nowakowski and Hayes, 2005).

$\mathrm{Ca}^{2+}$-imaging investigations during the development of embryonic cortex reveals distinct pattern of $\mathrm{Ca}^{2+}$ activities between the proliferative VZ, which contains the neural progenitors, and the IZ and MZ, which contains the postmitotic neurons. In the proliferative $\mathrm{VZ}$, the $\mathrm{Ca}^{2+}$ signals are mediated by the activation of metabotropic ATP receptors, most likely the purinergic $\mathrm{P} 2 \mathrm{Y} 1$ receptor and the release of $\mathrm{Ca}^{2+}$ through $\mathrm{IP}_{3} \mathrm{R}$. In the VZ there is no requirement of extracellular $\mathrm{Ca}^{2+}$ while the $\mathrm{Ca}^{2+}$ activities observed in the IZ and the $\mathrm{MZ}$ require $\mathrm{Ca}^{2+}$ influx through VOCCs (Owens and Kriegstein, 1998; Weissman et al., 2004). This discrepancy illustrates the differential expression of intracellular $\mathrm{Ca}^{2+}$ releasing channels, $\mathrm{Ca}^{2+}$ channels and receptors in the neocortex during early neurogenesis. Transcripts for the three main isoforms of the intracellular $\mathrm{Ca}^{2+}$ release channels the $\mathrm{IP}_{3} \mathrm{Rs}$ and the RyRs were detected in the mouse neocortex 

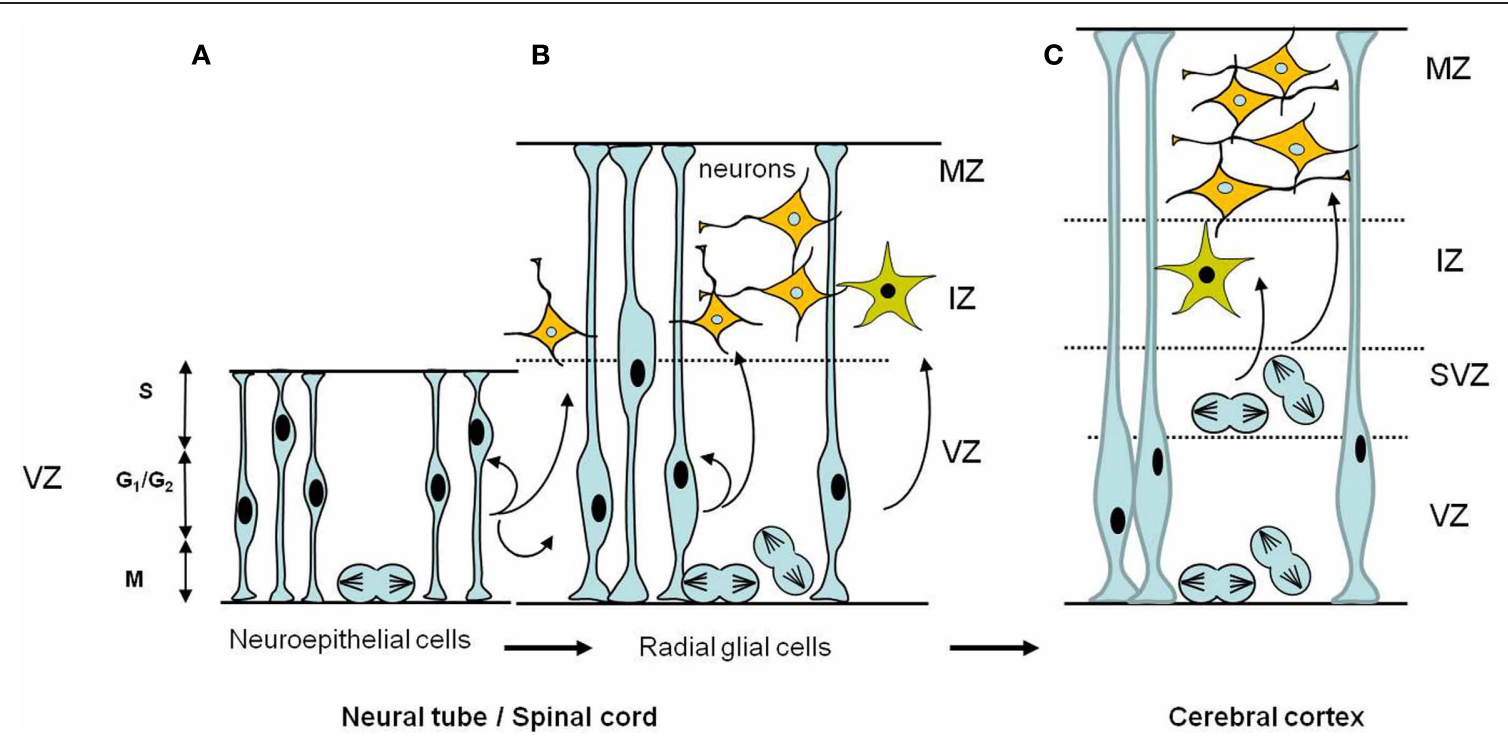

Cerebral cortex

FIGURE 3 | Schematic diagrams of the temporal development of neural progenitors in the early stages of CNS formation. (A) Early neuroepithelial progenitors of the ventricular zone are columnar cells self-renewing by symmetric divisions. These cells can generate some neurons. (B) As neurogenesis proceeds, neuroepithelial cells are transformed into radial glial cells which ultimately will give rise to neurons and glial cells. Radial glia cells can undergo either symmetric divisions, generating two progenitors or asymmetric divisions, producing a neural progenitor and a neuron. Also illustrated is the interkinetic nuclear migration of the nuclei during the cell cycle in the VZ. The nucleus of a single neuroepithelial cell moves during the
$\mathrm{G}_{1}$ phase, from the ventricular surface to the border of the $\mathrm{VZ}$ where it enters $S$ phase. During $G_{2}$, the nucleus moves down to the ventricular surface where it enter mitosis ( $M$ phase). Interkinetic nuclear migration in radial glial cells is confined to the VZ portion, does not extend to the border of the MZ. (C) In the cerebral cortex a second proliferative zone, the subventricular zone (SVZ), appears adjacent to the VZ; the postmitotic neurons and glia arise from both the ventricular and the subventricular zones. In the SVZ interkinetic nuclear migration does not occur, mitotic cells are found throughout the SVZ. Abbreviations: CNS, central nervous system; IZ, intermediate zone; $M Z$, marginal zone; SVZ, subventricular zone; VZ, ventricular zone. as early as embryonic day 11 (E11) and at the protein level, the IP3R-1 and RyR-2 are predominant at E13. The expression of these two isoforms increases progressively throughout development up to the adult age (Maric et al., 2000a; Rowitch, 2004; Mori et al., 2000; Faure et al., 2001). Moreover, while the expression of IP3R-1 is ubiquitous in proliferative VZ and neuronal zone, the expression of RyR-2 is mainly restricted to the neuronal cells population (Faure et al., 2001). Other works indicate that non-VOCCs $\mathrm{Ca}^{2+}$ channels are differentially regulated during neurogenesis. The neuroepithelial cells at E13 also express TRPC1 channels, whereas the expression of TRPC1 decreases in more fate-restricted cells such as radial glial cells which expressed TRPC5 and TRPC6 at high level (Fiorio Pla et al., 2005; Shin et al., 2010). Altogether these data raise the question of the function of these distinct $\mathrm{Ca}^{2+}$ transients in the control of the symmetric, proliferative division versus the asymmetric neurogenic division.

Accumulating evidences indicate that the kinetic of the cell cycle can directly influence the switch from proliferation to differentiation of the neural progenitors with the lengthening of the G1 phase acting as a trigger for differentiation while a shortened G1 phase is associated with the expansion of the neural progenitor pool (review in Salomoni and Calegari, 2010). Interestingly, $\mathrm{Ca}^{2+}$ signaling appears to control neuronal progenitor cells proliferation (Weissman et al., 2004; Lin et al., 2007) but also to be an important regulator of the switch from proliferation to neuronal differentiation. For instance, the $\mathrm{Ca}^{2+}$ waves observed in the VZ have been shown to control the entry in $S$ phase of radial glial cells organized in clusters (Weissman et al., 2004). The requirement of $\mathrm{Ca}^{2+}$ for cell cycle progression through $\mathrm{G}_{1} / \mathrm{S}$ phase was confirmed in mouse NSCs (Kapur et al., 2007; Resende et al., 2010). Another work indicates that bFGF-induced $\mathrm{Ca}^{2+}$ influx through TRPC1 is also involved in self-renewal of embryonic rat NSCs (Fiorio Pla et al., 2005). Using ESCs deficient in the RyR-2, it has been shown that RyR-2 activity is required to mediate the differentiation of neural precursors into neurons after activation of $\mathrm{GABA}_{\mathrm{A}}$ receptors or DHP-Ca ${ }^{2+}$ channels (Yu et al., 2008). This mechanism of excitation-neurogenesis coupling involving activation of DHP-Ca ${ }^{2+}$ channels has also been described in adult NSCs (Deisseroth et al., 2004). Finally, the TRPC5 channel has recently been shown to play a key role in the induction of neuronal differentiation from radial glial cells (Shin et al., 2010). However, the mechanisms involved in the activation of these channels remain to be elucidated. Likely mechanisms may involve the activity of the secreted signaling molecules, including Sonic hedgehog (Shh), Wnts, BMPs, FGFs, and retinoic acid known to pattern the vertebrate developing central nervous system (Borello and Pierani, 2010; Ulloa and Marti, 2010).

Recent data came to fill the gap between the spontaneous $\mathrm{Ca}^{2+}$ transients, the lengthening of G1 and the activity of cell cycle modulators during neurogenesis. Neuronal differentiation induced from P19 embryonic carcinoma cells is associated with spontaneous $\mathrm{Ca}^{2+}$ transients regulated by IP3R and RYR stores occurring during the G1/S transition. Furthermore, in the neural progenitor cells, ATP-evoked $\mathrm{Ca}^{2+}$ release from IP3R both 
increases proliferation and decreases the levels of the cell cycle regulators cyclin $\mathrm{A}$ and $\mathrm{E}$ bound to the cyclin-dependent kinase inhibitor p27 (Resende et al., 2010). A similar role for $\mathrm{Ca}^{2+}$ events has been found in primary human neural progenitor cells where mobilization of IP3-dependent $\mathrm{Ca}^{2+}$ stores lengthens the cell cycle and increases the number of intermediate neural progenitors. In this model, $\mathrm{Ca}^{2+}$ controls the duration of the cell cycle by increasing of the level of the p53 protein, a known regulator of the cyclin-dependent kinase inhibitor p21 (Garcia-Garcia et al., 2012). These new data raise additional questions about the mechanisms linking $\mathrm{Ca}^{2+}$ oscillations and the duration of G1 phase. One likely mechanism could involve the multifunctional Serine/threonine $\mathrm{Ca}^{2+} /$ Calmodulin stimulated protein kinases (CaMKs), particularly the CaMKI which has been shown to control G1 progression (Skelding et al., 2011). Although, numerous studies have implicated CaMKs in neuronal functions such as synaptic development and plasticity or learning and memory (Wayman et al., 2008; Fukunaga et al., 2009), their expression and function during early neurogenesis need to be explored.

Once neurons are specified, they undergo a process of maturation which includes the specification of neurotransmitters, the elaboration of axons, neurites, and synaptic connections to form functional networks. A number of excellent reviews illustrate the pivotal role played by intracellular $\mathrm{Ca}^{2+}$ signaling in these aspects (Lohmann, 2009; Michaelsen and Lohmann, 2010; TakemotoKimura et al., 2010; Spitzer, 2012). However, increasing evidences also point to the role of extracellular $\mathrm{Ca}^{2+}$ via activation of the Extracellular $\mathrm{Ca}^{2+}$-Sensing receptor (CaSR). CaSR which is constantly monitoring the level of extracellular $\mathrm{Ca}^{2+}$, belongs to the family C of GPCRs ( $G$-protein-coupled receptor), along with the metabotropic glutamate receptors (mGluRs) and the $\gamma$ aminobutyric acid (GABA) $\mathrm{B}$ receptors (Hofer and Brown, 2003). CaSR is localized in almost all areas of the brain including the circumventricular organs, the olfactory bulbs, the striatum, the orbital cortex, the cerebellum, and the hippocampus (Ruat et al., 1995; Yano et al., 2004; Bandyopadhyay et al., 2010). Furthermore, its expression in the central and peripheral nervous system is developmentally regulated (Ferry et al., 2000; Vizard et al., 2008). Interestingly, the highest levels of expression of CaSR correlate with a window of development during which neurite extension and branching occurs. Recently it has been shown that CaSR regulates the growth and the branching of developing sympathetic ganglion neurons and of hippocampal pyramidal neurons in mice (Vizard et al., 2008). The Extracellular CaSR has also been implicated in controlling other important functions in the nervous system including the migration of neurons synthesizing gonadotropin-releasing hormone ( $\mathrm{GnRH}$ neurons), and the regulation of neuronal excitability via the control of ion channels activity (review in Brown and Macleod, 2001; Bandyopadhyay et al., 2010). These data highlight the importance of the regulation of the extracellular $\mathrm{Ca}^{2+}$ homeostasis during neural development.

\section{$\mathrm{Ca}^{2+}$ TARGET GENES AND EARLY NEUROGENESIS}

The transcriptional control of early neurogenesis involves a large number of transcription factors which can act as positive or negative regulators. These include the Zic (Aruga, 2004; Aruga and
Mikoshiba, 2011), Sox (Wegner and Stolt, 2005), Xiro (GomezSkarmeta and Modolell, 2002), and bHLH (Bertrand et al., 2002; Sugimori et al., 2007) gene families. Control of gene expression by $\mathrm{Ca}^{2+}$ signaling may either be indirect through changes in the transactivating properties of transcription factors following the activation of $\mathrm{Ca}^{2+}$-dependent kinases and phosphatases (Dolmetsch et al., 2001; West et al., 2001; Kornhauser et al., 2002; Spotts et al., 2002) or direct through nuclear $\mathrm{Ca}^{2+}$ sensors. To date, DREAM (Downstream Regulatory Element (DRE) Antogonist Modulator) is the only $\mathrm{Ca}^{2+}$ sensor, which is known to bind specifically to DNA and to directly regulate transcription in a $\mathrm{Ca}^{2+}$-dependent manner. DREAM is a $\mathrm{Ca}^{2+}$-binding protein of the recoverin subfamily containing $4 \mathrm{EF}$-hands. In the absence of $\mathrm{Ca}^{2+}$ DREAM binds DNA on specific DRE site, located downstream from the TATA box, and represses transcription (Carrion et al., 1999; Mellstrom and Naranjo, 2001). Recently, a novel concept emerged around the idea that $\mathrm{Ca}^{2+}$ channel domains may act as transcription factor. The C-terminal fragment of the $\mathrm{Ca}_{\mathrm{v}} 1.2$ channel, called $\mathrm{Ca}^{2+}$ channel associated transcriptional regulator (CCAT) has been shown to have a nuclear localization and to be able to regulate gene expression. CCAT overexpression in neurons increases dendritic length (Gomez-Ospina et al., 2006).

\section{$\mathrm{Ca}^{2+}$ TARGET GENES AND NEURAL INDUCTION IN THE AMPHIBIANS}

The embryo of the amphibian Xenopus laevis and the animal cap cells have been extensively used to elucidate how the aforementioned transcription factors interact to regulate early neurogenesis (Rogers et al., 2009). Animal cap cells are also a good assay for screening downstream target genes of $\mathrm{Ca}^{2+}$ signaling during neural induction.

It has been previously shown that $\mathrm{Ca}^{2+}$ controls the expression of the immediate early gene $c$-fos and of two other transcription factors: XlPou2 and Zic3 (Leclerc et al., 1999). While Fos is a ubiquitous transcription factor, XlPou 2 and Zic3 are specific to neural determination and primary neural regulators (Witta et al., 1995; Nakata et al., 1997). Furthermore, the expression of XlPou2 in response to noggin in animal caps and the expression of Zic3 in the whole embryo require the presence of functional DHP$\mathrm{Ca}^{2+}$ channels (Leclerc et al., 2000). In an attempt to correlate the $\mathrm{Ca}^{2+}$ pattern with the expression pattern of early neural genes, a two-dimensional system of neural induction was used, the Keller explants (Keller and Danilchik, 1988). These explants extend from the blastopore lip up toward the animal pole and therefore contain the prospective neuroectoderm associated with the dorsal mesoderm (Keller et al., 1992). In such explants the accumulated pattern of $\mathrm{Ca}^{2+}$ transients correlates with the expression of Zic3, and treatment with nifedipine, a DHP-Ca ${ }^{2+}$ channel antagonist, blocks the $\mathrm{Ca}^{2+}$ transients and reduces the level of Zic3 expression (Leclerc et al., 2003). These results suggest that the function of the localized increase in $\left[\mathrm{Ca}^{2+}\right]_{i}$ that occurs in the dorsal ectoderm during neural induction might be to activate locally genes with proneural activity.

To identify new $\mathrm{Ca}^{2+}$ target genes involved in neural induction, a subtractive cDNA library was constructed between untreated (i.e., ectodermal cells fated to become epidermis) and caffeine-treated animal caps (15-45 min) (i.e., ectodermal cells 
fated to become neural) (Batut et al., 2003). Caffeine triggers neural induction via an increase in $\left[\mathrm{Ca}^{2+}\right]_{i}$ (Moreau et al., 1994), and thus allows the differential isolation of the earliest $\mathrm{Ca}^{2+}$ dependent genes involved in neural determination (Batut et al., 2003). A total of about 400 clones were screened, and about 30 clones were found to selectively hybridize to the neural-subtracted probe and not to the epidermis-subtracted probe. Among these clones, $x M L P$ encodes a MARCKS-like protein, a substrate for PKC (Zhao et al., 2001; Batut et al., 2003); $x$ PRMT1b is the Xenopus homologue of the mammalian arginine methyltransferase PRMT1 gene (Batut et al., 2005); xId3 (Wilson and Mohun, 1995), encodes HLH protein that acts as dominant negative inhibitor of bHLH transcription factors; and Xp54nrb encodes a protein which exhibits the RRM domains characteristic of RNA binding proteins, and implicated in pre-mRNA splicing steps (Neant et al., 2011). The spatio-temporal expression pattern of these genes is restricted to neural territories and their expression is triggered following the inhibition of BMP signaling by noggin. In addition, the expression of $x M L P$ and of $x P R M T 1 b$ is an early response to an increase in $\mathrm{Ca}^{2+}$ that does not require de novo protein synthesis and that the early expression of $x P R M T 1 b$ at the gastrula stage also occurs via a $\mathrm{Ca}^{2+}$-dependent mechanism mediated by the activation of DHP-sensitive $\mathrm{Ca}^{2+}$ channels.

Functional analysis of $x P R M T 1 b$ in Xenopus embryo demonstrates that it is required for neural induction. Overexpression of $x$ PRMT1b in the neural territories activates the expression of the neural precursor gene Zic3. Conversely, the utilization of a Morpholino-based approach, to block xPRMT1b translation, inhibits the expression of Zic3 in animal caps, and impairs anterior neural development in the whole embryo (Batut et al., 2005). Identical phenotypes were obtained with antagonists of DHP$\mathrm{Ca}^{2+}$ channels (Leclerc et al., 2000). These results suggest that during neural induction, $x P R M T 1 b$ provides a direct link between the $\left[\mathrm{Ca}^{2+}\right]_{i}$ increase and downstream events; a likely mechanism could involve methylation of early neural factors.

\section{PRONEURAL bHLH GENES AND $\mathrm{Ca}^{2+}$}

The bHLH proneural genes, which encode transcription factors of the basic Helix-Loop-Helix class, have been shown to be key regulators of neurogenesis. In vertebrates, proneural bHLH genes are first expressed in neuroepithelial cells that are already committed to neural fate (Bertrand et al., 2002). Proneural bHLH proteins bind DNA as heterodimeric complexes that are formed with another class of ubiquitously bHLH proteins, called E-proteins. Regulation of proneural bHLH may occur at different levels, including regulation of gene expression, transcriptional activities, subcellular localization, or post-translational modifications.

In adult neural precursor cells, the excitation-neurogenesis coupling via activation of DHP-Ca ${ }^{2+}$ channels rapidly induces the expression of the neuronal differentiation regulator, NeuroD, and inhibits the expression of two proneural gene inhibitors, Hes 1 and $I d 2$ (Deisseroth et al., 2004). Furthermore, over-expression of the $\mathrm{Ca}^{2+}$ binding protein, calbindin- $\mathrm{D}_{28 \mathrm{~K}}$ (Kim et al., 2006) in neural precursor cells promotes neurogenesis, induces the expression of the bHLH neuronal differentiation regulators, NeuroD and Mash1, and inhibits the expression of the proneural gene inhibitors, Hes1, Hes5, and Id2. The exact $\mathrm{Ca}^{2+}$-dependent mechanism that regulates NeuroD expression is not yet identified. However, possible mechanisms may involve the Hes1 transcriptional repressor. Hes 1 has been shown to repress the transcription of Mash1 by binding to Mash1 promoter; Hes 1 may also form heterodimers with Mash1 that do not bind to DNA (review in Kageyama et al., 2008). In addition to their abilities to form heterodimers with other bHLH proteins, there are evidences that some bHLH proteins, like E-protein and MyoD a myogenic bHLH regulator, may physically interact with $\mathrm{Ca}^{2+}$-loaded calmodulin but also with S-100 $\mathrm{Ca}^{2+}$ binding proteins; this interaction masks their DNA binding site (review in Hermann et al., 1998). To what extent this $\mathrm{Ca}^{2+}$-dependent mechanism may also regulate the transcriptional activity of proneural bHLH proteins remains to be established. However, proneural bHLH proteins have been shown to be post-translationally modified in a $\mathrm{Ca}^{2+}$-dependent manner. In rat hippocampal neural progenitors, the modulation of $\mathrm{Ca}^{2+}$ signaling by calbindin- $\mathrm{D}_{28 \mathrm{~K}}$ induces the phosphorylation of $\mathrm{Ca}^{2+}$ - and Calmodulin-dependent protein kinases (CaMKs), possibly CaMKII and of NeuroD at serine ${ }^{336}$ (Kim et al., 2006). This post-translational modification of NeuroD which has been described during neuronal differentiation of embryonic and adult neuronal progenitors is also involved in the control of dendritic outgrowth in granule neurons (Gaudilliere et al., 2004).

\section{THE NEUROGENIC TO GLIOGENIC SWITCH}

After neurons, the radial glial progenitors switch to generate glial cells. Macroglial cells of the central nervous system (CNS) comprise two major cell types; astrocytes and oligodendrocytes. The molecular mechanisms that underlie the specification of glial cells appear strikingly similar to those that regulate neurons specification (Rowitch and Kriegstein, 2010). Here we will exclusively consider the implication of $\mathrm{Ca}^{2+}$ signaling in the specification of astrocytes and oligodendrocytes during early development.

The mechanisms by which macroglial cells are generated from neural precursors involve different levels of regulation. One level of regulation occurs during the neurogenic period and renders the neuroepithelial precursors unable to generate glial cells, even in the presence of gliogenic signals. This could be achieved via the transcriptional repression of glial-specific genes by proneural bHLH genes. Another mechanism involves the repression of gliogenesis by neuregulin-1, a neurogenic factor. Activation of the receptor tyrosine kinase (RTK) Erb4 by neuregulin-1 induces the presenilin-dependent cleavage of the RTK. The cleaved intracellular domain of Erb4 translocates to the nucleus of undifferentiated neural precursors and represses the transcription of two astrocyte specific genes, GFAP (glial fibrillary acidic protein) and $S 100 \beta$ which encodes a $\mathrm{Ca}^{2+}$-binding protein, thereby inhibiting the differentiation of the neural progenitors into astrocytes (Sardi et al., 2006). Despite the fact that presenilin forms the catalytic subunit of the $\gamma$-secretase complex, increasing evidences suggest that presenilin is part of a mechanism that control $\mathrm{Ca}^{2+}$ homeostasis. Presenilin is an integral membrane protein of the ER (Annaert et al., 1999) that has been shown to function as a passive $\mathrm{ER} \mathrm{Ca}^{2+}$ leak channels (Tu et al., 2006). Other works have shown that presenilin can interact with the $\mathrm{IP}_{3} \mathrm{R} \mathrm{Ca}^{2+}$ release channel and modulates its gating (Cheung et al., 2008); presenilin can also regulate the activity of the SERCA pump (Green 
et al., 2008). The function of presenilin both in regulating $\mathrm{Ca}^{2+}$ homeostasis and in the inhibition of astrocytic fate raised the possibility that the $\mathrm{Ca}^{2+}$ waves observed in the radial glial progenitors cells during the neurogenic period not only promote neurogenesis but also repress gliogenesis. Conversely, a positive neuronal feedback mechanism has been shown to promote gliogenesis. The neurotrophic cytokine CT-1 generated by embryonic cortical neurons is a powerful astrocytic signal, which activates the JAK-STAT signaling pathway (Barnabe-Heider et al., 2005). However, in cortical neuronal precursors another pathway able to promote astrocytes differentiation involves the activation of the seven transmembrane-spanning domains receptor PAC1 by the Pituitary Adenylate Cyclase Activating Peptide (PACAP). PAC1 activation by PACAP triggers the production of cAMP, and a cAMP-dependent $\mathrm{Ca}^{2+}$ influx. Cebolla et al, have shown that the transcriptional activation of GFAP in response to PACAP is mediated by DREAM and requires the functional integrity of the $\mathrm{Ca}^{2+}$-binding EF-hand domains of DREAM (Cebolla et al., 2008). Unexpectedly, during astrocytes differentiation, DREAM is acting as a transcriptional transactivator of the GFAP gene and not as a repressor (Scsucova et al., 2005). In fact, two binding sites for DREAM have been identified on the GFAP promoter, located upstream of the TATA box rather than downstream (Cebolla et al., 2008). The mechanism by which DREAM controls the expression of GFAP may involve changes in DREAM protein conformation, interactions with other gliogenic specific transcription factors, and cross-talk with the JAK-STAT signaling pathway (review in Vallejo, 2009).

There are some evidences indicating that $\mathrm{Ca}^{2+}$ signaling may also regulate the specification of the oligodendrocyte lineage. A subtractive approach to characterize genes expressed in the ventral neuroepithelium of chick spinal cord at the time of oligodendrocyte specification identify several elements of the $\mathrm{Ca}^{2+}$ toolkit, including a specific auxiliary subunit $(\alpha 2-\delta 1)$ of a voltagedependent $\mathrm{Ca}^{2+}$ channel; Ankyrin-2, $\alpha 2$, a membrane adaptor protein, requires to anchor ion channels, exchangers, and pumps to the plasma membrane; and slow troponin $\mathrm{C}$, a $\mathrm{Ca}^{2+}$-binding protein, expressed in cardiac muscle (Braquart-Varnier et al., 2004). Other works identify the Extracellular CaSR as a key element for oligodendrocyte specification. CaSR is expressed in all cells of the CNS with predominance in oligodendrocyte lineage (Chattopadhyay et al., 2008). CaSR is up-regulated when NSCs are specified to oligodendrocyte progenitor cells (OPCs) its expression remains at a high level in pre-oligodendrocyte cells, and then decreases in mature oligodendrocytes. Furthermore, activation of CaSR with high extracellular $\mathrm{Ca}^{2+}$ or with spermine, an agonist of CaSR present in the CNS, promotes OPCs proliferation and induces the expression of Myelin Basic Protein, a marker for oligodendrocyte maturation (Chattopadhyay et al., 2008; Bandyopadhyay et al., 2010). This work provides the demonstration that $\mathrm{Ca}^{2+}$, in addition to a role as second messenger, acting intracellularly, may also act extracellularly as a first messenger.

\section{CONCLUSION AND PERSPECTIVES}

In this review, we have briefly summarized the recent advances in early neurogenesis, a rapidly moving field, and then focused specifically on several regulatory events that are modulated by $\mathrm{Ca}^{2+}$, including short term effects or long-lasting modifications. The different functions of $\mathrm{Ca}^{2+}$ signaling during neurogenesis illustrate the versatility of $\mathrm{Ca}^{2+}$ both as a second and a first messenger.

While much is known about how the different $\mathrm{Ca}^{2+}$ signals are generated during the initial phases of nervous system formation, much less is known about the EF-hand calcium proteins involved in the transmission of these $\mathrm{Ca}^{2+}$ signals. The members of the EF-hand superfamily can be divided into two main categories according to their calcium affinity or their ability to change conformation following $\mathrm{Ca}^{2+}$ binding (Leclerc et al., 2009). Calmodulins (CaM), the S100 superfamily, and the neuronal calcium sensors such as DREAM constitute the first group of calcium sensors involved in $\mathrm{Ca}^{2+}$ signaling. The second group is constituted by $\mathrm{Ca}^{2+}$ buffering proteins such as calbindin.

The role of $\mathrm{Ca}^{2+}$ during neural induction in the amphibians is mainly focused on the triggering of $\mathrm{Ca}^{2+}$ signaling via the activation of $\mathrm{Ca}^{2+}$ channels and the downstream genes whose expression is controlled directly or indirectly by $\mathrm{Ca}^{2+}$ (Moreau et al., 2009). However, some evidences indicate that EF-hand $\mathrm{Ca}^{2+}$ proteins may be involved in signal transduction. The upregulation of FOS-related protein by Noggin or a DHP-Ca ${ }^{2+}$ channels agonist is inhibited by KN62, a specific inhibitor of CaMKinase, suggesting that CaMs and CaMKs are candidates to decode the $\mathrm{Ca}^{2+}$ signals during amphibian neural induction (Leclerc et al., 1999). Calcineurin, a $\mathrm{Ca}^{2+} / \mathrm{CaM}$-dependent phosphatase (CaN or PP2B) is maternally expressed and throughout development including neural induction (Saint-Saneyoshi et al., 2000). Finally, the expression of the calcium sensor DREAM has been found to be restricted to neuroectoderm during early development in Xenopus laevis (I. Neant unpublished results).

During early neurogenesis, EF-hand proteins such as CaMs and CaMKs are also involved (Skelding et al., 2011). In rat hippocampal neural progenitors, $\mathrm{Ca}^{2+}$ signaling is modulated by Calbindin-D28K (Kim et al., 2006), during the neurogenic to gliogenic switch the $S 100 \beta$ protein is important for the differentiation of neural progenitors into astrocytes (Sardi et al., 2006) and during astrocyte differentiation triggered by the pituitary adenylate cyclase activating peptide, it has been shown that transcriptional activation of GFAP is mediated by DREAM (Cebolla et al., 2008).

Specific $\mathrm{Ca}^{2+}$ signals which are decoded by different $\mathrm{Ca}^{2+}$ sensors proteins and the different $\mathrm{Ca}^{2+}$ binding properties of these sensors (affinity, conformational changes) allow a fine tuning of the $\mathrm{Ca}^{2+}$ signaling. Among the $\mathrm{Ca}^{2+}$ sensors proteins more EF-hand $\mathrm{Ca}^{2+}$ proteins play certainly essential roles during early neural development. This field of research needs more development in the future.

\section{ACKNOWLEDGMENTS}

We apologize to those whose work we could not cite owing to space limitations. Work in our laboratory is supported by CNRS (Centre National de la Recherche Scientifique), GDRE 731, Procore/Ministère des Affaires Etrangères/RGC grants (Hong Kong, PRC) and the LIA "Rocade" (Laboratoire International Associé from CNRS). 


\section{REFERENCES}

Annaert, W. G., Levesque, L., Craessaerts, K., Dierinck, I., Snellings, G., Westaway, D., GeorgeHyslop, P. S., Cordell, B., Fraser, P., and De Strooper, B. (1999). Presenilin 1 controls gammasecretase processing of amyloid precursor protein in pre-golgi compartments of hippocampal neurons. J. Cell Biol. 147, 277-294.

Arcuri, F., Papa, S., Meini, A., Carducci, A., Romagnoli, R., Bianchi, L., Riparbelli, M. G., Sanchez, J. C., Palmi, M., Tosi, P., and Cintorino, M. (2005). The translationally controlled tumor protein is a novel calcium binding protein of the human placenta and regulates calcium handling in trophoblast cells. Biol. Reprod. 73, 745-751.

Aruga, J. (2004). The role of Zic genes in neural development. Mol. Cell. Neurosci. 26, 205-221.

Aruga, J., and Mikoshiba, K. (2011). Role of BMP, FGF, calcium signaling, and zic proteins in vertebrate neuroectodermal differentiation. Neurochem. Res. 36, 12861292.

Bandyopadhyay, S., Tfelt-Hansen, J., and Chattopadhyay, N. (2010). Diverse roles of extracellular calcium-sensing receptor in the central nervous system. J. Neurosci. Res. 88, 2073-2082.

Barnabe-Heider, F., Wasylnka, J. A., Fernandes, K. J., Porsche, C., Sendtner, M., Kaplan, D. R., and Miller, F. D. (2005). Evidence that embryonic neurons regulate the onset of cortical gliogenesis via cardiotrophin-1. Neuron 48, 253-265.

Barth, L. G., and Barth, L. J. (1964). Sequential induction of the presumptive epidermis of the Rana pipiens gastrula. Biol. Bull. 127, 413-427.

Batut, J., Neant, I., Leclerc, C., and Moreau, M. (2003). xMLP is an early response calcium target gene in neural determination in Xenopus laevis. J. Soc. Biol. 197, 283-289.

Batut, J., Vandel, L., Leclerc, C., Daguzan, C., Moreau, M., and Neant, I. (2005). The $\mathrm{Ca}^{2+}$-induced methyltransferase xPRMT1b controls neural fate in amphibian embryo. Proc. Natl. Acad. Sci. U.S.A. 102, 15128-15133.

Bayer, S. A., and Altman, J. (1991). Neocortical Development. New York: Raven Press.

Berridge, M. J., Lipp, P., and Bootman, M. D. (2000). The versatility and universality of calcium signalling. Nat. Rev. Mol. Cell Biol. 1, 11-21.
Bertrand, N., Castro, D. S., and Guillemot, F. (2002). Proneural genes and the specification of neural cell types. Nat. Rev. Neurosci. 3, 517-530.

Bommer, U. A., and Thiele, B. J. (2004). The translationally controlled tumour protein (TCTP). Int. J. Biochem. Cell Biol. 36, 379-385.

Borello, U., and Pierani, A. (2010). Patterning the cerebral cortex: traveling with morphogens. Curr. Opin. Genet. Dev. 20, 408-415.

Braquart-Varnier, C., Danesin, C., Clouscard-Martinato, C., Agius, E., Escalas, N., Benazeraf, B., Ai, X., Emerson, C., Cochard, P., and Soula, C. (2004). A subtractive approach to characterize genes with regionalized expression in the gliogenic ventral neuroepithelium: Identification of chick sulfatase 1 as a new oligodendrocyte lineage gene. Mol. Cell. Neurosci. 25, 612-628.

Brown, E. M., and Macleod, R. J. (2001). Extracellular calcium sensing and extracellular calcium signaling. Physiol. Rev. 81, 239-297.

Cai, C., and Grabel, L. (2007). Directing the differentiation of embryonic stem cells to neural stem cells. Dev. Dyn. 236, 3255-3266.

Carrion, A. M., Link, W. A., Ledo, F., Mellstrom, B., and Naranjo, J. R. (1999). DREAM is a $\mathrm{Ca}^{2+}$. regulated transcriptional repressor. Nature 398, 80-84.

Catterall, W. A., Perez-Reyes, E., Snutch, T. P., and Striessnig, J. (2005). International Union of Pharmacology. XLVIII. Nomenclature and structurefunction relationships of voltage-gated calcium channels. Pharmacol. Rev. 57, 411-425.

Cebolla, B., Fernandez-Perez, A., Perea, G., Araque, A., and Vallejo, M. (2008). DREAM mediates cAMPdependent, $\mathrm{Ca}^{2+}$-induced stimulation of GFAP gene expression and regulates cortical astrogliogenesis. J. Neurosci. 28, 6703-6713.

Chalmers, A. D., Welchman, D., and Papalopulu, N. (2002). Intrinsic differences between the superficial and deep layers of the Xenopus ectoderm control primary neuronal differentiation. Dev. Cell 2, 171-182.

Chattopadhyay, N., Espinosa-Jeffrey, A., Tfelt-Hansen, J., Yano, S., Bandyopadhyay, S., Brown, E. M., and De Vellis, J. (2008). Calcium receptor expression and function in oligodendrocyte commitment and lineage progression: Potential impact on reduced myelin basic protein in CaR-null mice. J. Neurosci. Res. 86, 2159-2167.
Cheung, K. H., Shineman, D., Muller, M., Cardenas, C., Mei, L., Yang, J., Tomita, T., Iwatsubo, T., Lee, V. M., and Foskett, J. K. (2008). Mechanism of $\mathrm{Ca}^{2+}$ disruption in Alzheimer's disease by presenilin regulation of $\mathrm{InsP} 3$ receptor channel gating. Neuron 58, 871-883.

De Robertis, E. M., and Kuroda, H. (2004). Dorsal-ventral patterning and neural induction in Xenopus embryos. Annu. Rev. Cell Dev. Biol. 20, 285-308.

Deisseroth, K., Singla, S., Toda, H., Monje, M., Palmer, T. D., and Malenka, R. C. (2004). Excitationneurogenesis coupling in adult neural stem/progenitor cells. Neuron 42 , 535-552.

Denton, R. M. (2009). Regulation of mitochondrial dehydrogenases by calcium ions. Biochim. Biophys. Acta 1787, 1309-1316.

Distasi, C., Munaron, L., Laezza, F., and Lovisolo, D. (1995). Basic fibroblast growth factor opens calciumpermeable channels in quail mesencephalic neural crest neurons. Eur. J. Neurosci. 7, 516-520.

Distasi, C., Torre, M., Antoniotti, S. Munaron, L., and Lovisolo, D. (1998). Neuronal survival and calcium influx induced by basic fibroblast growth factor in chick ciliary ganglion neurons. Eur. J. Neurosci. 10, 2276-2286.

Dolmetsch, R. E., Pajvani, U., Fife, K., Spotts, J. M., and Greenberg, M. E. (2001). Signaling to the nucleus by an L-type calcium channelcalmodulin complex through the MAP kinase pathway. Science 294, 333-339.

Drean, G., Leclerc, C., Duprat, A. M., and Moreau, M. (1995). Expression of L-type $\mathrm{Ca}^{2+}$ channel during early embryogenesis in Xenopus laevis. Int. J. Dev. Biol. 39, 1027-1032.

Faure, A. V., Grunwald, D., Moutin, M. J., Hilly, M., Mauger, J. P., Marty, I., De Waard, M., Villaz, M., and Albrieux, M. (2001). Developmental expression of the calcium release channels during early neurogenesis of the mouse cerebral cortex. Eur. J. Neurosci. 14, 1613-1622.

Ferry, S., Traiffort, E., Stinnakre, J., and Ruat, M. (2000). Developmental and adult expression of rat calciumsensing receptor transcripts in neurons and oligodendrocytes. Eur. J. Neurosci. 12, 872-884

Fiorio Pla, A., Maric, D., Brazer, S. C., Giacobini, P., Liu, X., Chang, Y. H., Ambudkar, I. S., and Barker, J. L. (2005). Canonical transient receptor potential 1 plays a role in basic fibroblast growth factor
(bFGF)/FGF receptor-1-induced $\mathrm{Ca}^{2+}$ entry and embryonic rat neural stem cell proliferation. J. Neurosci. 25, 2687-2701.

Fish, J. L., Dehay, C., Kennedy, H., and Huttner, W. B. (2008). Making bigger brains-the evolution of neuralprogenitor-cell division. J. Cell Sci. 121, 2783-2793.

Fukunaga, K., Shioda, N., and Miyamoto, E. (2009). "The function of CaM kinase II in synaptic plasticity and spine formation," in Handbook of Neurochemistry and Molecular Neurobiology,ed K. Mikoshiba (New York, NY: Springer Science), 163-183.

Garcia-Garcia, E., Pino-Barrio, M. J., Lopez-Medina, L., and MartinezSerrano, A. (2012). Intermediate progenitors are increased by lengthening of cell cycle through calcium signaling and p53 expression in human Neural Progenitors. Mol. Biol. Cell. 23, 1167-1180.

Gaspard, N., and Vanderhaeghen, P. (2010). Mechanisms of neural specification from embryonic stem cells. Curr. Opin. Neurobiol. 20, 37-43.

Gaudilliere, B., Konishi, Y., De La Iglesia, N., Yao, G., and Bonni, A. (2004). A CaMKII-NeuroD signaling pathway specifies dendritic morphogenesis. Neuron 41, 229-241.

Gaulden, J., and Reiter, J. F. (2008). Neur-ons and neur-offs: Regulators of neural induction in vertebrate embryos and embryonic stem cells. Hum. Mol. Genet. 17, R60-R66.

Gomez-Ospina, N., Tsuruta, F., Barreto-Chang, O., Hu, L., and Dolmetsch, R. (2006). The C terminus of the L-type voltage-gated calcium channel $\mathrm{Ca}(\mathrm{V}) 1.2$ encodes a transcription factor. Cell 127, 591-606.

Gomez-Skarmeta, J. L., and Modolell, J. (2002). Iroquois genes: genomic organization and function in vertebrate neural development. Curr. Opin. Genet. Dev. 12, 403-408.

Gotz, M., and Huttner, W. B. (2005). The cell biology of neurogenesis. Nat. Rev. Mol. Cell Biol. 6, 777-788.

Green, K. N., Demuro, A., Akbari, Y., Hitt, B. D., Smith, I. F., Parker, I., and Laferla, F. M. (2008). SERCA pump activity is physiologically regulated by presenilin and regulates amyloid beta production. J. Cell Biol. 181, 1107-1116.

Grunz, H., and Tacke, L. (1989). Neural differentiation of Xenopus laevis ectoderm takes place after disaggregation and delayed reaggregation without inducer. Cell Differ. Dev. 28, 211-217. 
Hemmati-Brivanlou, A., and Melton, D. (1997). Vertebrate neural induction. Annu. Rev. Neurosci. 20, 43-60.

Hermann, S., Saarikettu, J., Onions, J., Hughes, K., and Grundstrom, T. (1998). Calcium regulation of basic helix-loop-helix transcription factors. Cell Calcium 23, 135-142.

Hofer, A. M., and Brown, E. M. (2003). Extracellular calcium sensing and signalling. Nat. Rev. Mol. Cell Biol. 4, 530-538.

Kageyama, R., Ohtsuka, T., and Kobayashi, T. (2008). Roles of Hes genes in neural development. Dev. Growth Differ. 50(Suppl. 1), S97-S103.

Kapur, N., Mignery, G. A., and Banach, K. (2007). Cell cycle-dependent calcium oscillations in mouse embryonic stem cells. Am. J. Physiol. Cell Physiol. 292, C1510-C1518.

Keller, R., and Danilchik, M. (1988). Regional expression, pattern and timing of convergence and extension during gastrulation of Xenopus laevis. Development 103, 193-209.

Keller, R., Shih, J., Sater, A. K., and Moreno, C. (1992). Planar induction of convergence and extension of the neural plate by the organizer of Xenopus. Dev. Dyn. 193, 218-234.

Kim, J. H., Lee, J. A., Song, Y. M., Park, C. H., Hwang, S. J., Kim, Y. S., Kaang, B. K., and Son, H. (2006). Overexpression of calbindin-D28K in hippocampal progenitor cells increases neuronal differentiation and neurite outgrowth. FASEB J. 20, 109-111.

Kornhauser, J. M., Cowan, C. W., Shaywitz, A. J., Dolmetsch, R. E., Griffith, E. C., Hu, L. S., Haddad, C., Xia, Z., and Greenberg, M. E. (2002). CREB transcriptional activity in neurons is regulated by multiple, calcium-specific phosphorylation events. Neuron 34, 221-233.

Kuroda, H., Fuentealba, L., Ikeda, A., Reversade, B., and De Robertis, E. M. (2005). Default neural induction: Neuralization of dissociated Xenopus cells is mediated by Ras/MAPK activation. Genes Dev. 19, 1022-1027.

Lamb, T. M., Knecht, A. K., Smith, W. C., Stachel, S. E., Economides, A. N., Stahl, N., Yancopolous, G. D., and Harland, R. M. (1993). Neural induction by the secreted polypeptide noggin. Science 262, 713-718.

Leclerc, C., Daguzan, C., Nicolas, M. T., Chabret, C., Duprat, A. M., and Moreau, M. (1997). L-type calcium channel activation controls the in vivo transduction of the neuralizing signal in the amphibian embryos. Mech. Dev. 64, 105-110.
Leclerc, C., Duprat, A. M., and Moreau, M. (1995). In vivo labelling of L-type $\mathrm{Ca}^{2+}$ channels by fluorescent dihydropyridine: Correlation between ontogenesis of the channels and the acquisition of neural competence in ecotderm cells from Pleurodeles waltl embryos. Cell Calcium 17, 216-224.

Leclerc, C., Duprat, A. M., and Moreau, M. (1999). Noggin upregulates Fos expression by a calciummediated pathway in amphibian embryos. Dev. Growth Differ. 41, 227-238.

Leclerc, C., Lee, M., Webb, S. E., Moreau, M., and Miller, A. L. (2003). Calcium transients triggered by planar signals induce the expression of ZIC3 gene during neural induction in Xenopus. Dev. Biol. 261, 381-390.

Leclerc, C., Rizzo, C., Daguzan, C., Neant, I., Batut, J., Auge, B., and Moreau, M. (2001). Neural determination in Xenopus laevis embryos: Control of early neural gene expression by calcium. J. Soc. Biol. 195, 327-337.

Leclerc, E., Sturchler, E., and Heizmann, C. W. (2009). "Calcium regulation by EF-hand protein in the brain," in Handbook of Neurochemistry and Molecular Neurobiology, ed K. Mikoshiba (New York, NY: Springer Science), 510-532.

Leclerc, C., Webb, S. E., Daguzan, C., Moreau, M., and Miller, A. L. (2000). Imaging patterns of calcium transients during neural induction in Xenopus laevis embryos. J. Cell Sci. 113(Pt 19), 3519-3529.

Lee, K. W., Moreau, M., Neant, I., Bibonne, A., and Leclerc, C. (2009). FGF-activated calcium channels control neural gene expression in Xenopus. Biochim. Biophys. Acta 1793, 1033-1040.

Lin, H. H., Bell, E., Uwanogho, D., Perfect, L. W., Noristani, H., Bates, T. J., Snetkov, V., Price, J., and Sun, Y. M. (2010). Neuronatin promotes neural lineage in ESCs via $\mathrm{Ca}(2+)$ signaling. Stem Cells 28, 1950-1960.

Lin, J. H., Takano, T., Arcuino, G., Wang, X., Hu, F., Darzynkiewicz, Z., Nunes, M., Goldman, S. A., and Nedergaard, M. (2007). Purinergic signaling regulates neural progenitor cell expansion and neurogenesis. Dev. Biol. 302, 356-366.

Lohmann, C. (2009). Calcium signaling and the development of specific neuronal connections. Prog. Brain Res. 175, 443-452.

Maric, D., Maric, I., and Barker, J. L. (2000). Developmental changes in cell calcium homeostasis during neurogenesis of the embryonic rat cerebral cortex. Cereb. Cortex 10, 561-573.

Maric, D., Maric, I., Chang, Y. H., and Barker, J. L. (2000). Stereotypical physiological properties emerge during early neuronal and glial lineage development in the embryonic rat neocortex. Cereb. Cortex 10, 729-747.

Mellstrom, B., and Naranjo, J. R. (2001). $\mathrm{Ca}(2+)$-dependent transcriptional repression and derepression: DREAM, a direct effector. Semin. Cell Dev. Biol. 12, 59-63.

Michaelsen, K., and Lohmann, C. (2010). Calcium dynamics at developing synapses: Mechanisms and functions. Eur. J. Neurosci. 32, 218-223.

Michalak, M., Groenendyk, J., Szabo, E., Gold, L. I., and Opas, M. (2009). Calreticulin, a multi-process calcium-buffering chaperone of the endoplasmic reticulum. Biochem. J. 417, 651-666.

Moreau, M., Leclerc, C., GualandrisParisot, L., and Duprat, A.-M. (1994). Increased internal $\mathrm{Ca}^{2+}$ mediates neural induction in the amphibian embryo. Proc. Natl. Acad. Sci. U.S.A. 91, 12639-12643.

Moreau, M., Neant, I., Webb, S. E., Miller, A. L., and Leclerc, C. (2008). Calcium signalling during neural induction in Xenopus laevis embryos. Philos. Trans. R. Soc. Lond. B Biol. Sci. 363, 1371-1375.

Moreau, M., Webb, S. E., Neant, I., Miller, A. L., and Leclerc, C. (2009). "Calcium signalling and cell fate determination during neural induction in amphibian embryos," in Handbook of Neurochemistry and Molecular Neurobioloy, ed K. Mikoshiba (New York, NY: Springer Science), 3-14.

Mori, F., Fukaya, M., Abe, H., Wakabayashi, K., and Watanabe, M. (2000). Developmental changes in expression of the three ryanodine receptor mRNAs in the mouse brain. Neurosci. Lett. 285, 57-60

Nakata, K., Nagai, T., Aruga, J., and Mikoshiba, K. (1997). Xenopus Zic 3 , a primary regulator both in neural and neural crest developement. Proc. Natl. Acad. Sci. U.S.A. 94, 11980-11985.

Neant, I., Deisig, N., Scerbo, P., Leclerc, C., and Moreau, M. (2011). The RNA-binding protein Xp54nrb isolated from a $\mathrm{Ca}(2)$-dependent screen is expressed in neural structures during Xenopus laevis development. Int. J. Dev. Biol. 55, 923-931.
Nowakowski, R., and Hayes, N. (2005). "Cell proliferation in the developing mammalian brain," in Developmental Neurobiology, 4th edn., eds M. S. Rao and M. Jacobson (New York, NY: Plenum Publishers), 21-39.

Okabayashi, K., and Asashima, M. (2003). Tissue generation from amphibian animal caps. Curr. Opin. Genet. Dev. 13, 502-507.

Okano, H., and Temple, S. (2009). Cell types to order: temporal specification of CNS stem cells. Curr. Opin. Neurobiol. 19, 112-119.

Oppenheimer, J. M. (1936). Transplantation experiments on developing teleosts (Fundulus and Perca). J. Exp. Zool. 72, 409-437.

Owens, D. F., and Kriegstein, A. R. (1998). Patterns of intracellular calcium fluctuation in precursor cells of the neocortical ventricular zone. J. Neurosci. 18, 5374-5388.

Puro, D. G., and Mano, T. (1991). Modulation of calcium channels in human retinal glial cells by basic fibroblast growth factor: a possible role in retinal pathobiology. $J$. Neurosci. 11, 1873-1880.

Resende, R. R., Adhikari, A., Da Costa, J. L., Lorencon, E., Ladeira, M. S., Guatimosim, S., Kihara, A. H., and Ladeira, L. O. (2010). Influence of spontaneous calcium events on cell-cycle progression in embryonal carcinoma and adult stem cells. Biochim. Biophys. Acta 1803, 246-260.

Rogers, C. D., Moody, S. A., and Casey, E. S. (2009). Neural induction and factors that stabilize a neural fate. Birth Defects Res. C Embryo Today 87, 249-262.

Rowitch, D. H. (2004). Glial specification in the vertebrate neural tube Nat. Rev. Neurosci. 5, 409-419.

Rowitch, D. H., and Kriegstein, A. R. (2010). Developmental genetics of vertebrate glial-cell specification. Nature 468, 214-222.

Ruat, M., Molliver, M. E., Snowman, A M., and Snyder, S. H. (1995). Calcium sensing receptor: Molecular cloning in rat and localization to nerve terminals. Proc. Natl. Acad. Sci. U.S.A. 92, 3161-3165.

Saint-Jeannet, J. P., Huang, S., and Duprat, A. M. (1990). Modulation of neural commitment by changes in target cell contacts in Pleurodeles waltl. Dev. Biol. 141, 93-103.

Saneyoshi, T., Kume, S., Natsume, T., and Mikoshiba, K. (2000). Molecular cloning and expression profile of Xenopus calcineurin A subunit(1). Biochim Biophys Acta 1499, 164-170. 
Salomoni, P., and Calegari, F. (2010). Cell cycle control of mammalian neural stem cells: Putting a speed limit on G1. Trends Cell Biol. 20, 233-243.

Sardi, S. P., Murtie, J., Koirala, S., Patten, B. A., and Corfas, G. (2006). Presenilin-dependent ErbB4 nuclear signaling regulates the timing of astrogenesis in the developing brain. Cell 127, 185-197.

Scsucova, S., Palacios, D., Savignac, M., Mellstrom, B., Naranjo, J. R., and Aranda, A. (2005). The repressor DREAM acts as a transcriptional activator on Vitamin $\mathrm{D}$ and retinoic acid response elements. Nucleic Acids Res. 33, 2269-2279.

Sharpe, C. R., Fritz, A., De Robertis, E. M., and Gurdon, J. B. (1987). A homeobox-containing marker of posterior neural differentiation shows the importance of predetermination in neural induction. Cell 50, 749-758.

Shin, H. Y., Hong, Y. H., Jang, S. S., Chae, H. G., Paek, S. L., Moon, H. E., Kim, D. G., Kim, J., Paek, S. H., and Kim, S. J. (2010). A role of canonical transient receptor potential 5 channel in neuronal differentiation from $\mathrm{A} 2 \mathrm{~B} 5$ neural progenitor cells. PLoS One 5, e10359.

Skelding, K. A., Rostas, J. A., and Verrills, N. M. (2011). Controlling the cell cycle: the role of calcium/calmodulin-stimulated protein kinases I and II. Cell Cycle $10,631-639$.

Spemann, H., and Mangold, H. (1924). Über die induktion von embryonalanlagen durch implantation artfremder organisatoren. Wilhelm Roux Arch Entwickl. Mech. Org. 100, 599-638.

Spitzer, N. C. (2012). Activitydependent neurotransmitter respecification. Nat. Rev. Neurosci. 13, 94-106.

Spotts, J. M., Dolmetsch, R. E., and Greenberg, M. E. (2002). Timelapse imaging of a dynamic phosphorylation-dependent protein-protein interaction in mammalian cells. Proc. Natl. Acad. Sci. U.S.A. 99, 15142-15147.

Stern, C. D. (2005). Neural induction: Old problem, new findings, yet more questions. Development 132, 2007-2021.
Streit, A., Berliner, A. J., Papanayotou, C., Sirulnik, A., and Stern, C. D. (2000). Initiation of neural induction by FGF signalling before gastrulation. Nature 406, 74-78.

Sugimori, M., Nagao, M., Bertrand, N., Parras, C. M., Guillemot, F., and Nakafuku, M. (2007). Combinatorial actions of patterning and HLH transcription factors in the spatiotemporal control of neurogenesis and gliogenesis in the developing spinal cord. Development 134, 1617-1629.

Takemoto-Kimura, S., Suzuki, K., Kamijo, S., Ageta-Ishihara, N., Fujii, H., Okuno, H., and Bito, H. (2010). Differential roles for CaM kinases in mediating excitationmorphogenesis coupling during formation and maturation of neuronal circuits. Eur. J. Neurosci. 32, 224-230.

Tu, H., Nelson, O., Bezprozvanny, A., Wang, Z., Lee, S. F., Hao, Y. H., Serneels, L., De Strooper, B., Yu, G., and Bezprozvanny, I. (2006). Presenilins form ER $\mathrm{Ca}^{2+}$ leak channels, a function disrupted by familial Alzheimer's disease-linked mutations. Cell 126, 981-993.

Ulloa, F., and Marti, E. (2010). Wnt won the war: Antagonistic role of Wnt over Shh controls dorsoventral patterning of the vertebrate neural tube. Dev. Dyn. 239, 69-76.

Vallejo, M. (2009). PACAP signaling to DREAM: A cAMP-dependent pathway that regulates cortical astrogliogenesis. Mol. Neurobiol. 39, 90-100.

Vizard, T. N., O'Keeffe, G. W., Gutierrez, H., Kos, C. H., Riccardi, D., and Davies, A. M. (2008). Regulation of axonal and dendritic growth by the extracellular calciumsensing receptor. Nat. Neurosci. 11, 285-291.

Waddington, C. H. (1933). Induction of the primitive streak and its derivatives in the chick. J. Exp. Biol. $10,38-46$.

Waddington, C. H. (1936). Organizers in mammalian development. Nature 138, 125.

Wang, D., and Gao, L. (2005). Proteomic analysis of neural differentiation of mouse embryonic stem cells. Proteomics 5, 4414-4426.

Wang, K., Xue, T., Tsang, S. Y., Van Huizen, R., Wong, C. W., Lai, K. W., Ye, Z., Cheng, L., Au, K.
W., Zhang, J., Li, G. R., Lau, C. P., Tse, H. F., and Li, R. A. (2005). Electrophysiological properties of pluripotent human and mouse embryonic stem cells. Stem Cells 23, 1526-1534.

Wayman, G. A., Lee, Y. S., Tokumitsu, H., Silva, A. J., and Soderling, T. R. (2008). Calmodulin-kinases: Modulators of neuronal development and plasticity. Neuron 59, 914-931.

Webb, S. E., and Miller, A. L. (2007). $\mathrm{Ca}^{2+}$ signalling and early embryonic patterning during zebrafish development. Clin. Exp. Pharmacol. Physiol. 34, 897-904.

Wegner, M., and Stolt, C. C. (2005). From stem cells to neurons and glia: a Soxist's view of neural development. Trends Neurosci. 28, 583-588.

Weissman, T. A., Riquelme, P. A., Ivic, L., Flint, A. C., and Kriegstein, A. R. (2004). Calcium waves propagate through radial glial cells and modulate proliferation in the developing neocortex. Neuron 43, 647-661.

West, A. E., Chen, W. G., Dalva, M. B., Dolmetsch, R. E., Kornhauser, J. M., Shaywitz, A. J., Takasu, M. A., Tao, X., and Greenberg, M. E. (2001). Calcium regulation of neuronal gene expression. Proc. Natl. Acad. Sci. U.S.A. 98, 11024-11031.

Wijnholds, J., Chowdhury, K., Wehr, R., and Gruss, P. (1995). Segmentspecific expression of the neuronatin gene during early hindbrain development. Dev. Biol. 171, 73-84.

Wilson, R., and Mohun, T. (1995), XIdx, a dominant negative regulator of bHLH function in early Xenopus embryos. Mech. Dev. 49, 211-222.

Witta, S. E., Agarwal, V. R., and Sato, S. M. (1995). XIPOU 2, a noggininducible gene, has direct neuralizing activity. Development 121, 721-730.

Yamada, M., Tanemura, K., Okada, S., Iwanami, A., Nakamura, M., Mizuno, H., Ozawa, M., Ohyama-Goto, R., Kitamura, N., Kawano, M., Tan-Takeuchi, K., Ohtsuka, C., Miyawaki, A., Takashima, A., Ogawa, M., Toyama, Y., Okano, H., and Kondo, T. (2007). Electrical stimulation modulates fate determination of differentiating embryonic stem cells. Stem Cells 25 , 562-570.
Yanagida, E., Shoji, S., Hirayama, Y., Yoshikawa, F., Otsu, K., Uematsu, H., Hiraoka, M., Furuichi, T., and Kawano, S. (2004). Functional expression of $\mathrm{Ca}^{2+}$ signaling pathways in mouse embryonic stem cells. Cell Calcium 36, 135-146.

Yano, S., Brown, E. M., and Chattopadhyay, N. (2004). Calcium-sensing receptor in the brain. Cell Calcium 35, 257-264

Yoon, T., Kim, M., and Lee, K. (2006). Inhibition of $\mathrm{Na}, \mathrm{K}-$ ATPase-suppressive activity of translationally controlled tumor protein by sorting nexin 6. FEBS Lett. 580, 3558-3564.

Yu, H. M., Wen, J., Wang, R., Shen, W. H., Duan, S., and Yang, H. T. (2008). Critical role of type 2 ryanodine receptor in mediating activity-dependent neurogenesis from embryonic stem cells. Cell Calcium 43, 417-431.

Zhao, H., Cao, Y., and Grunz, H. (2001). Isolation and characterization of a Xenopus gene (XMLP) encoding a MARCKS-like protein. Int. J. Dev. Biol. 45, 817-826.

Zimmerman, L. B., De Jesus-Escobar, J. M., and Harland, R. M. (1996). The Spemann organizer signal noggin binds and inactivates bone morphogenetic protein 4. Cell 86, 599-606.

Conflict of Interest Statement: The authors declare that the research was conducted in the absence of any commercial or financial relationships that could be construed as a potential conflict of interest.

Received: 12 March 2012; accepted: 25 April 2012; published online: 14 May 2012.

Citation: Leclerc C, Néant I and Moreau $M$ (2012) The calcium: an early signal that initiates the formation of the nervous system during embryogenesis. Front. Mol. Neurosci. 5:64. doi: 10.3389/fnmol. 2012.00064

Copyright (c) 2012 Leclerc, Néant and Moreau. This is an open-access article distributed under the terms of the Creative Commons Attribution Non Commercial License, which permits noncommercial use, distribution, and reproduction in other forums, provided the original authors and source are credited. 